\title{
PROTOTIP OSCILLATING WATER COLUMB (OWC)
}

\author{
${ }^{(1)}$ Rendi, ${ }^{(2)}$ Jainal Arifin \\ (1)(2) Program Studi Teknik Mesin, Universitas Islam Kalimantan MAAB \\ Jl. Adhyaksa no.2 kayutangi banjarmasin \\ Email : rendi.teknikmesin@gmail.com
}

\begin{abstract}
Abstrak
Salah satu cara yang dapat digunakan untuk membangkitkan gelombang laut adalah dengan Wave Energy Converter (WEC) atau konversi energi gelombang laut. Salah satunya adalah yang banyak diteliti Konversi energi gelombang laut jenis Oscillating Water Columb (OWC). Sistem OWC memiliki 4 komponen utama yaitu chamber, air turbine, generator, dan pontoon. Chamber berfungsi untuk tempat osilasi antara air dan udara, air turbine berfungsi untuk menangkap energi dari udara yang akan digunakan untuk memutar generator, sehingga menghasilkan energi listrik. Penelitian ini bertujuan merancang bangun Oscillating Water. Oscillating Water Columb yang dirancang dengan volume columb $20 \mathrm{~cm}^{3}$ memiliki kinerja yang lebih baik dibandingkan dengan Oscillating Water Columb yang dirancang dengan volume columb $10 \mathrm{~cm}^{3}$
\end{abstract}

Kata Kunci : Wave Energy Converter, Oscillating Water Colum, kinerja

\begin{abstract}
One way that can be used to generate ocean waves is the Wave Energy Converter (WEC). One of them is the most studied type of ocean wave energy conversion Oscillating Water Columb $(O W C)$. The OWC system has 4 main components namely chamber, air turbine, generator, and pontoon. Chamber serves to place the oscillation between water and air, water turbine serves to capture energy from the air that will be used to rotate the generator, thus producing electrical energy. This study aims to design Oscillating Water. Oscillating Water Columb which is designed with a volume of $20 \mathrm{~cm} 3$ columb has better performance compared to Oscillating Water Columb which is designed with a volume of $10 \mathrm{~cm} 3$.
\end{abstract}

Keywords : Wave Energy Converter, Oscillating Water Colum, performance

\section{PENDAHULUAN}

Pemakaian energi listrik semakin hari semakin besar, sehingga menuntuk semu orang untuk selalu berinovasi untuk bisa menghasilkan energi listrik. Salah satu yang banyak di kemangkan adalah energi listrik dari memanfaatkan potensi alam misalnya gelombang laut, arus air, kecepatan angin dan energi panas bumi.
Oscillating Water Column $(O W C)$ adalah teknologi pembangkit listrik yang menggunakan tenaga gelombang laut sebagai penggerak turbinnya. Untuk lebih mengenal teknologi Oscillating Water Column (OWC) ini dan bagaimana cara kerjanya, dapat dilihat pada sketsa gambar berikut: 


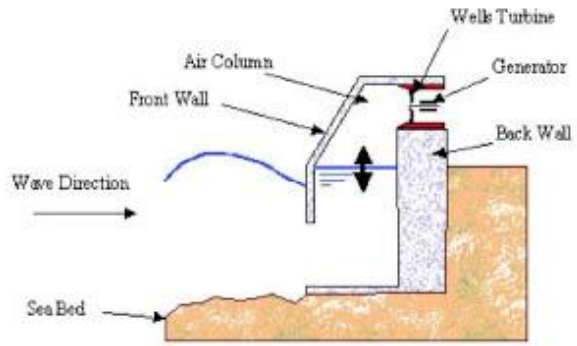

Prinsip kerja alat OWC ini adalah mengubah energi gelombang laut menjadi energi listrik berdasarkan prinsip kerja kolom isolasi. Gelombang yang datang dari arah laut akan menabrak bangunan OWC ini dimana pada bagian bawah bangunan ini terdapat kolom tebuka untuk masuknya air laut, karena tumbukan gelombang air laut ini kemudian air laut yg terdapat pada bagian dalam chamber OWC akan berisolasi naik dan turun sehingga menimbulkan peristiwa sedot dan hisap pada kolom udara di atasnya (prinsip kerja pompa). Gerakan air yang naik turun serta menimbulkan peristiwa sedot hisap pada kolom udara diatasnya inilah yang akan menggerakan turbin.

Berdasarkan prinsip kerja Oscillating Water Column (OWC) bahwa alat ini sangat mudah dibuat dan kinerja dari sistem ini dipengaruhi oleh besar atau kecilnya colum air dan tinggi gelombangnya.

Sistem OWC memiliki 4 komponen utama yaitu chamber, air turbine, generator, dan pontoon. Chamber berfungsi untuk tempat osilasi antara air dan udara, air turbine berfungsi untuk menangkap energi dari udara yang akan digunakan untuk memutar generator, sehingga menghasilkan energi listrik. Penelitian ini bertujuan merancang bangun Oscillating Water. Oscillating Water Columb yang dirancang dengan volume columb 10 $\mathrm{cm}^{3} 15 \mathrm{~cm}^{3} 20 \mathrm{~cm}^{3}$

\section{METODE PENELITIAN}

Tahap-tahap yang dilakukan dalam penelitian ini adalah:

\section{Pembuatan Kolam Ombak}

Kolam ombak dibuat menyerupai aquarium yang terbuat adri kaca yang doirancang supaya mendapatkan kompresi dari gelombang ombakyang digunakan untuk memutar turbin. Kolam ombak dibuat dengan 3 volume yaitu 10 $\mathrm{cm}^{3} 15 \mathrm{~cm}^{3} 20 \mathrm{~cm}^{3}$ untuk menguji apakah ada pengaruh terhadap kinerja Oscillating Water. Oscillating Water Columb

\section{Alat pembuat Ombak}

Alat pembuat ombak dibuat dari mika yang kerjanya mendorong air supaya menjadi ombak.

\section{Turbin Angin}

Turbin angin menggunakan jenis propeler yang berfungsi penerima gaya dorong dari gelombang air.

\section{Perakitan}

Semua komponen yang sudah di siapkan kemudian dirakit menjadi satu sehingga terbentuk Oscillating Water. Oscillating Water Columb

\section{Pengujian}

Untuk mengetahui kinerja, maka dilakukian pengujian dengan parameter pengujian adalah kecepatan putaran turbin

\section{Analisa Data}

Data akan dianalisa untuk mendapatkan pengaruh perubahan volume terhadap kinerja Oscillating Water. Oscillating Water Columb

\section{HASIL DAN PEMBAHASAN 1. Kolam Ombak}

Berikut adalah hasil perhitungan kolam ombak untuk masing-masing volume yaitu $10 \mathrm{~cm}^{3} 15 \mathrm{~cm}^{3} 20$ $\mathrm{cm}^{3}$

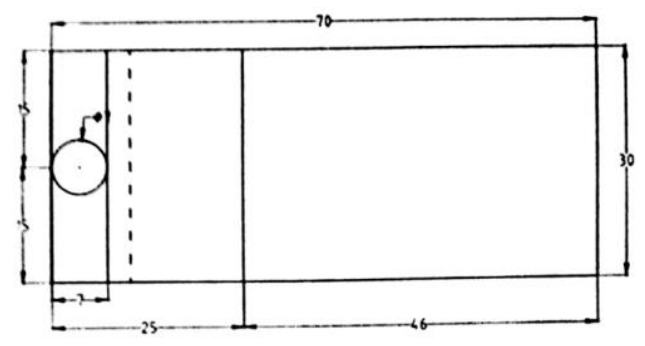




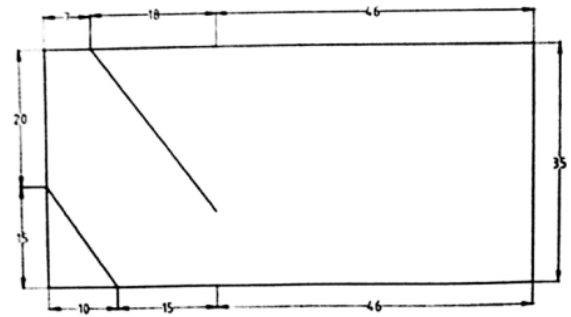

Gambar 2 volume columb $10 \mathrm{~cm}^{3}$
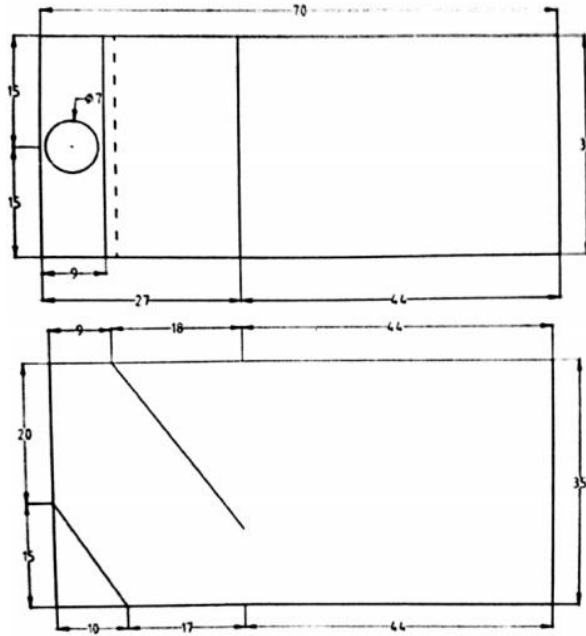

Gambar 3 volume columb $15 \mathrm{~cm}^{3}$
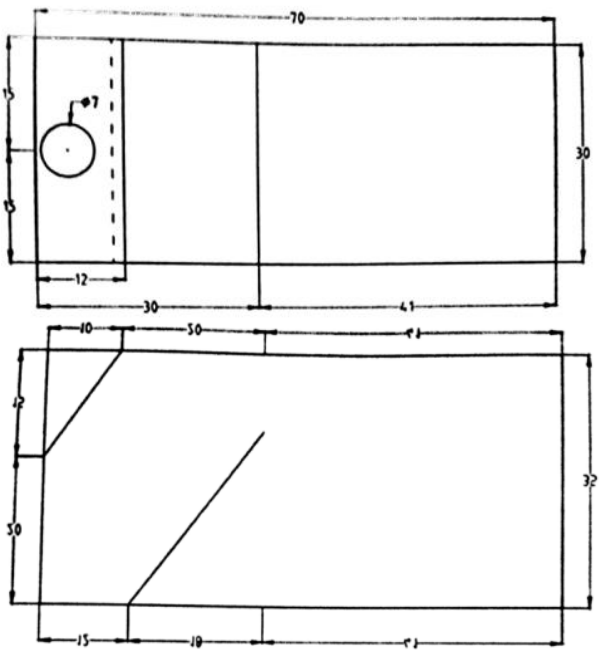

Gambar 4 volume columb $20 \mathrm{~cm}^{3}$

\section{Alat Pembuat Ombak}

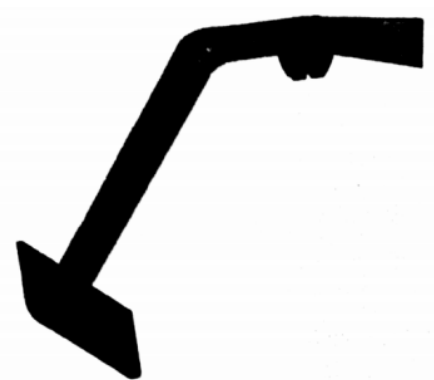

Gambar 5. Pembaut Ombak

\section{Turbin Angin}
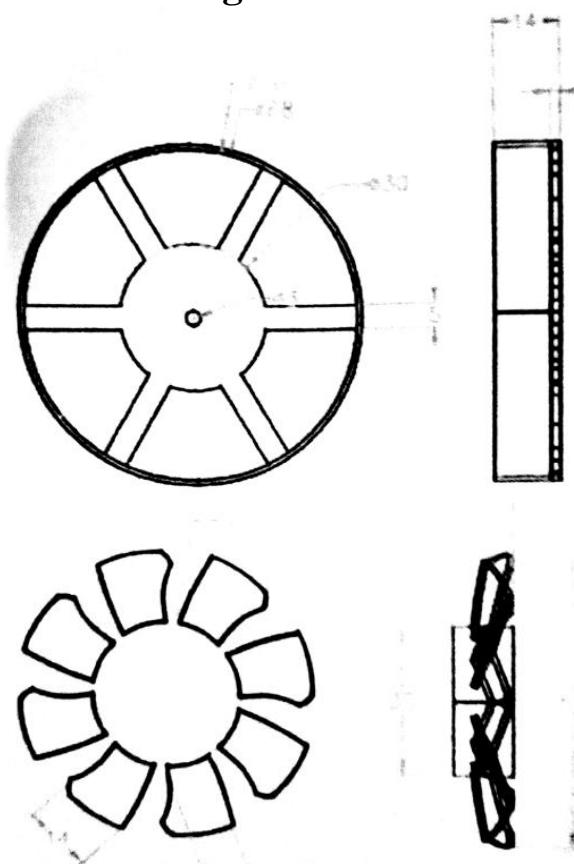

Gambar 6 Turbin Angin

\section{Perakitan}

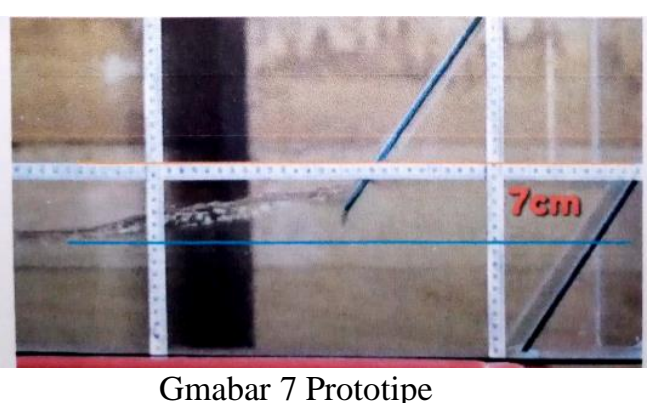

\section{Pengujian}

Pengujian RPM dengan Tacometer

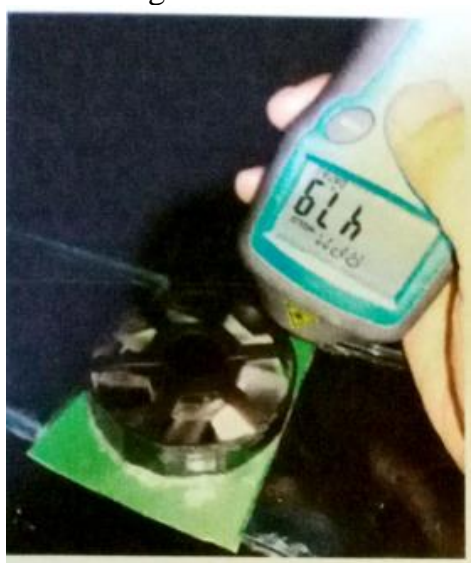

Gamabar 8 Proses Pengujian RPM 
Tabel 1. Hasil Pengujian RPM

\begin{tabular}{|c|c|c|c|}
\hline \multirow{2}{*}{$\begin{array}{c}\text { tinggi } \\
\text { gelomban } \\
\mathrm{g}(\mathrm{cm})\end{array}$} & \multicolumn{3}{|c|}{ Putaran Turbin (RPM) } \\
\cline { 2 - 4 } & $\begin{array}{c}\text { Volume } \\
\text { kolam 10 } \\
\mathrm{cm}\end{array}$ & $\begin{array}{c}\text { Volume } \\
\text { kolam 15 } \\
\mathrm{cm}\end{array}$ & $\begin{array}{c}\text { Volume } \\
\text { kolam 20 } \\
\mathrm{cm}\end{array}$ \\
\hline 3 & 22 & 47 & 68 \\
\hline 5 & 72 & 116 & 130 \\
\hline 7 & 103 & 125 & 153 \\
\hline 10 & 245 & 356 & 454 \\
\hline
\end{tabular}

Berikut adalah grafik perbandingan antara tinggi gelombang dan volume kolam terhadap RPM

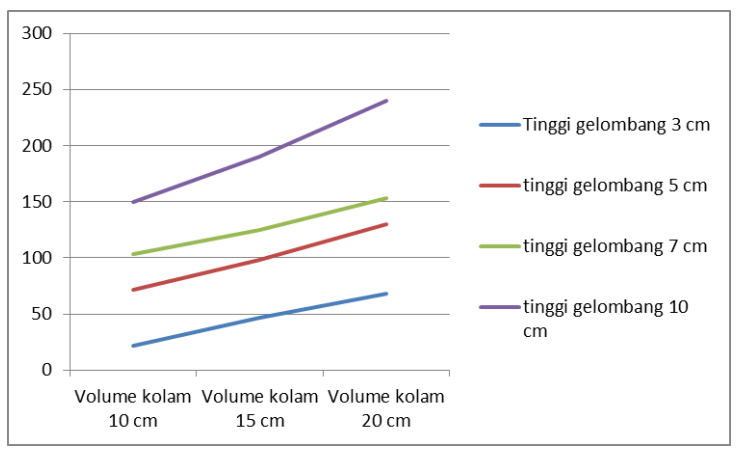

Gambar 9 grafik perbandingan antara tinggi gelombang dan volume kolam terhadap RPM

\section{Analisa Data}

Dari gambar 9 yaitu grafik perbandingan antara tinggi gelombang dan volume kolam terhadap RPM terlihat bahwa prototipe yang dibuat mampu bekerja dengan baik ini dibuktikan dengan kemampuannya untuk menghasilan putaran turbin, pada kolam air dengan volume $10 \mathrm{~cm}^{3}$ menghasilakn rpm turbin yang paling rendah sedangkan polume kolam air 20 $\mathrm{cm}^{3}$ menghasilakn rpm turbin yang paling tinggi. Ini di sebabkan karena semakin besarnya volume maka semakin banyak udara yang mampu ditampung oleh kolam tersebut sehingga menyebabkan hembusan udara semakin banyak yang dapat dikonversi untuk memutar turbin.

Ketinggian gelombang juga berpengaruh seperti disajikan pada gambar 9, semakin tinggi gelombang maka akan semakin cepat putaran turbin. Dan begitu juga sebaliknya.

\section{KESIMPULAN}

1. Adanya pengaruh yang signifikan terhadap perubahan ketinggian gelombang dan verubahan volume kolam air terhadap kinerja Oscillating Water Columb

2. Oscillating Water Columb yang dirancang dengan volume columb 20 $\mathrm{cm}^{3}$ memiliki kinerja yang lebih baik.

\section{REFERENSI}

[1] Arief Prastiatomo.2014. 'rancang bangun miniatur pembangkit gelombang laut' Jakarta

[2] Udaidilah dkk. "studi potensi pembangkit listrik tenaga ombak di perairan laut sepu pulau sepu kabupaten malang" Briwijaya.

[3] Kurniawan, I. (2014) 'Kajian Eksperimental dan Numerikal Turbin Air Helikal Gorlov Untuk Twist Angle 60', Jurnal Teknobiologi, 5(1), pp. 7-13.

[4] Pietersz, Richard, Rudy Soenoko, S. W. (2013) 'Pengaruh Jumlah Sudu Terhadap', Jurnal Rekayasa Mesin, 4(2), pp. 93-100.

[5] Mulkan, I., Hantoro, R. and Nugroho, G. (2012) 'Analisa Performansi Turbin Arus Sungai Vertikal Aksis Terhadap Penambahan Variasi Panjang', Jurnal Teknik Pomits, 1(1), Pp. 1-5. 